\title{
A collective effort to identify and quantify geo-energy risks
}

\author{
Sanchez Roa C, Mitchell T, Jones A, Oelkers E, Striolo A, Stanton-Yonge A, Saldi \\ G, Mahzari P
}

University College London

\section{Introduction}

Sustainable exploitation of the subsurface is one of the main challenges arising from the current demand for energy and raw materials. This pressing need has led to increasing efforts in alternative technologies such as geothermal energy, enhanced oil/gas recovery and carbon sequestration. However, the implementation of these new practices to extract or store fluids in geological reservoirs has also generated important questions in our communities regarding environmental risk and the legislation required to ensure sustainable development. Science for Clean Energy (S4CE) is a Horizon 2020 consortium created to detect, quantify and mitigate the risks connected with geo-energy operations in the subsurface. The project links efforts from academic institutions, industry energy operators, industrial partners and research institutes in order to solve fundamental scientific questions that can help us better understand the subsurface and generate better exploitation practices.

One of S4CE's main goals is to better understand the permeability of the Earth's crust, an area of common interest for industry and academic researchers. Understanding the factors and processes controlling the evolution of permeability in time is therefore key for a sustainable exploitation of the subsurface. The permeability of the crust governs industries of high economic value and that are fundamental for human survival such as oil and gas production, geothermal energy, mineralised ores, and the exploration and production of underground drinking water sources. Both the viability and potential of these industries are controlled by the fluid conductivity of the reservoir rocks which is strongly dictated by fractures. The knowledge acquired of fluid flow in the subsurface not only contributes to improving productivity but also aids prediction of flow direction and fluid overpressures in the subsurface. This will help equip geologists and engineers with tools to mitigate some of the associated risks, such as: induced seismicity, leakage of hazardous nuclear waste and aquifer contamination.

In this study, we examine the geology of reservoirs used for geothermal energy extraction and carbon dioxide capture. We use a combination of field geology, photogrammetry, mineral analysis and experimental rock mechanics to understand fracture networks and fluid flow paths of two geologically diverse reservoirs in Europe: 1) the Hengill geothermal system in south-west Iceland, and 2) the Carnmenellis granite geothermal system in Cornwall (UK). These results aim to provide a way to refine numerical models that predict fluid flow and contribute to the quantification of the associated risks of exploiting the subsurface.

\section{Methods}

Photogrammetry: exposed outcrops in the two study areas were mapped using unmanned aerial vehicles (UAV). First, an analogue outcrop of fractured Cornish granite exposed on south Cornwall and corresponding to the Tregonning Godolphin granite and a second outcrop in SW-Iceland, $500 \mathrm{~m}$ west of the Hellisheidi power plant on the Hengill geothermal system. A Phantom 3 professional drone fitted with GPS and GLONASS was used to acquire high-resolution images from three altitudes $(20,40$ and $60 \mathrm{~m})$ and two camera angles $\left(90^{\circ}\right.$ and $60^{\circ}$ from the surface). The aerial photographs obtained with the UAV were selected and processed using Agisoft Photoscan Professional software 
(version 1.3.2) to generate a point cloud, mesh, texture map and digital elevation model (DEM) representing the surface model as a regular grid of height values. Finally, an orthomosaic was generated to allow for the measurement of true distances given that the final image is adjusted for topographic relief, lens distortion and camera tilt. The images were used to identify and digitalise structural orientation of fracture networks, and where then quantified using the software FraqPaq (Healy et al., 2017).

Experimental rock mechanics: rock physical properties of the samples are explored using He-injection picnometry for rock porosity measurements; water permeability measurements were conducted using the steady state method, using a servo-controlled permeameter with a $100 \mathrm{MPa}$ hydrostatic pressure vessel and two $70 \mathrm{MPa}$ pore fluid intensifiers. Permeability was measured at a constant pore pressure of $5 \mathrm{MPa}$ and increasing confining pressure at $10 \mathrm{MPa}$ ramps. Uniaxial and triaxial deformation experiments were conducted in an unconfined uniaxial press and a triaxial deformation apparatus with servo-controlled axial loading and fluid pressure systems. New methods and technologies will also be used in this project to help answer crucial scientific questions. One of them is the new true triaxial deformation apparatus in UCL, which is equipped with a confining pressure vessel and a six-axis pore-fluid pressure system that can pressurise samples to reservoir conditions and permits permeability measurements in three orthogonal directions to simulate the natural differential stress conditions found within the Earth's crust. This new technology will permit us to evaluate the influence of the intermediate principal stress on the permeability of natural systems by allowing deformation experiments with three independently controlled stress paths $\left(\sigma_{1}>\sigma_{2}>\sigma_{3}\right)$. Experiments will be carried out on both Cornish granite and Icelandic basalt to evaluate fluid flow under true triaxial conditions for the systems in this study. The comparison between naturally and experimentally fractured reservoirs can provide a strong basis to validate and extrapolate laboratory results to natural settings, which can significantly contribute to the design and optimisation of sustainable operations.

\section{Case studies}

1) The Hengill geothermal system in south-west Iceland

The Hengill geothermal system is located in a divergent plate boundary between the North America and Eurasia plates. New oceanic crust is constantly created along this rifting area and forms the current basaltic platform that constitutes Iceland (Einarsson, 2008). The Hengill geothermal system is located on a triple junction between the volcanic zones of Reykjanes Peninsula (RP), Western Volcanic Zone (WVZ), and South Iceland Seismic Zone (SISZ) (Hardarson et al., 2009), where the basaltic rocks host the Hellisheidi Geothermal Power Plant. The Hellisheidi Power Plant is located $25 \mathrm{~km} \mathrm{SW}$ of Reykjavik, commissioned in 2016 and expanded on several occasions. The plant is capable of producing electricity using double-flash steam cycles for energy generation in high pressure units. The water separated from this process is then flushed through heat exchangers that heat the surrounding ground water to be pumped to Reykavik and used for space heating (Gunnarson and Mortensen, 2016). Besides the energy generation capabilities of this plant, the Hellisheidi field has also pioneered implementation of $\mathrm{CO}_{2}$ and $\mathrm{H}_{2} \mathrm{~S}$ capture and storage in deep geological formations as a mechanism for waste management. The $\mathrm{CO}_{2}$ mineralisation of reactive silicate rocks, involves the dissolution of the rock in the proximities to the injection, and the release of divalent metal cations, primarily $\mathrm{Ca}^{2+}, \mathrm{Mg}^{2+}, \mathrm{Fe}^{2+}$ and $\mathrm{Mn}^{2+}$, to the fluid. These ions then react with dissolved $\mathrm{CO}_{2}$ to precipitate carbonate minerals (Oelkers et al., 2008).

Images acquired in the Husmuli area were integrated into photogrammetric and digital elevation models. Fracture patterns traced and analysed from the resulting models show several orientations due to the overlap of two tectonic regimes in this part of Iceland: an extensional regime from the rifting, and the transform zone of South Iceland Seismic Zone. As a consequence, it is natural to question which of this fracture systems are interconnected and which are not. Measurements and observations during field work allowed the identification of planar structures with indicators of fluid-rock interaction. These structures were mapped using aerial photography at the outcrop scale and manually separated from other fracture families. Structural results of the isolated fracture family show 
consistent orientation $\mathrm{N} 75^{\circ} \mathrm{E}$ which coincides with tracer tests in injection wells in the area. Mineralogical indicators for fluid-rock interaction in this area can significantly help in the identification of fluid paths in the subsurface. The initial porosity of these Icelandic basalts ranges between 22 to $36 \%$ in the intersection of lava flows, where degassing promotes vesicles. Matrix permeability is in the order of $1.6 \times 10^{-19} \mathrm{~m}^{2}$ from effective pressures of 5 to $95 \mathrm{MPa}$, however lava flow contacts tend to increase permeability in one to two orders of magnitude.

2) The Carnmenellis granite geothermal system in Cornwall, England.

The Cornish batholith is a granitic body outcropping in several locations of Cornwall and the target formation of the United Downs Deep Geothermal Power project (UDDGP), currently under drilling operations. Cornish granite yields especially high temperatures due to the radioactive decay of some of the elements that constitute this rock body, resulting in the area of England with highest geothermal gradient. UDDGP is an ongoing geothermal project, partly funded by the European Regional Development Fund which aims to be the first deep geothermal power project in the UK. The planning of this project builds on the knowledge acquired during past geothermal exploration campaigns and the Hot Dry Rock (HDR) project completed in the 1980s, which confirmed rock temperatures up to $190{ }^{\circ} \mathrm{C}$ through circulation tests in Cornish granite (Richards et al., 1992).

The specific target of the proposed wells is the Carnmenellis intrusion, part of a sequence of the lateto post-orogenic magmatism events related to the Variscan Orogeny (Shail and Wilkinson, 1994). Intense deformation during the late Carboniferous to early Permian during the Variscan Orogeny shaped the main compressional features in the area (Rattey and Sanderson, 1984; Leveridge et al., $1984 ; 1990)$, while a following extensional regime dominated the area creating late- to post-Variscan extensional faulting associated with many of the mineralisation events in Cornwall. The current UDDGP project plans to target a permeable geological structure called the Porthtowan Fault Zone, which lies about $800 \mathrm{~m}$ to the west of the United Downs site. Two deep holes (wells) will be drilled into the fault; one for injection at about 2,500 m depth and one for production at 4,500 $\mathrm{m}$ depth. The temperature at the bottom of the production well is expected to be about $190{ }^{\circ} \mathrm{C}$.

Images acquired in Rinsey Cove were used to construct photogrammetric and digital elevation models that allow remote study of the outcrop and 3D modelling of the fracture network (Fig 1.). 2D fracture quantification shows that the outcrop is dominated by two subvertical fracture families, striking $75^{\circ}-255^{\circ}$, and a second set with close to N-S strike. The most frequent fracture length is $2 \mathrm{~m}$, and higher crack densities tend to be located towards the contact with older units and fault planes. The best fit to the fracture distribution data is achieved with a lognormal distribution described by a mean $\mu=0.046$, and standard deviation $\sigma=0.824$. The calculated permeability tensor is: $\mathrm{k}_{1}=$ $6.7057 \mathrm{e}-17 \mathrm{~m}^{\wedge} 2$ with an azimuth of $\mathrm{k}_{1}=75.816123^{\circ}$. Permeability tensors calculated with a $\lambda=0.5$ estimated from the connectivity plot and a scaled aperture according to equation $A=a L^{\wedge} b$, where factor $\mathrm{a}=2 \mathrm{e}^{-6}$ and exponent $\mathrm{b}=1$. Orientation of the permeability tensor is calculated using linearised trends for principal stresses in the Carnmenellis granite (Pine and Batchelor, 1984) for a depth of $3.5 \mathrm{~km}: \sigma_{1}=78.7 \mathrm{MPa}, \sigma_{2}=56.7 \mathrm{MPa}, \sigma_{3}=13.7 \mathrm{MPa}$. The calculated permeability results are similar to measured hydraulic parameters during the Hot Dry Rock project in the Carnmenellis granite, reported to be $10 \mu$ darcy $\sim 9.8 \times 10^{-18} \mathrm{~m}^{2}$ (Pine and Ledingham, 1983). The initial porosity of the Carnmenellis granite ranges from $1.2 \%$ to $0.6 \%$ for the fine and coarse specimens respectively. Permeability measurements ranged from $1 \times 10^{-19} \mathrm{~m}^{2}$ to $1 \times 10^{-20} \mathrm{~m}^{2}$ from effective pressures of 5 to $20 \mathrm{MPa}$. These experimental measurements of the Carnmenellis granite show low matrix porosity and permeability indicating that fracture networks are the main factor controlling fluid flow in this reservoir and highlight the importance of characterising fracture networks in this system. 

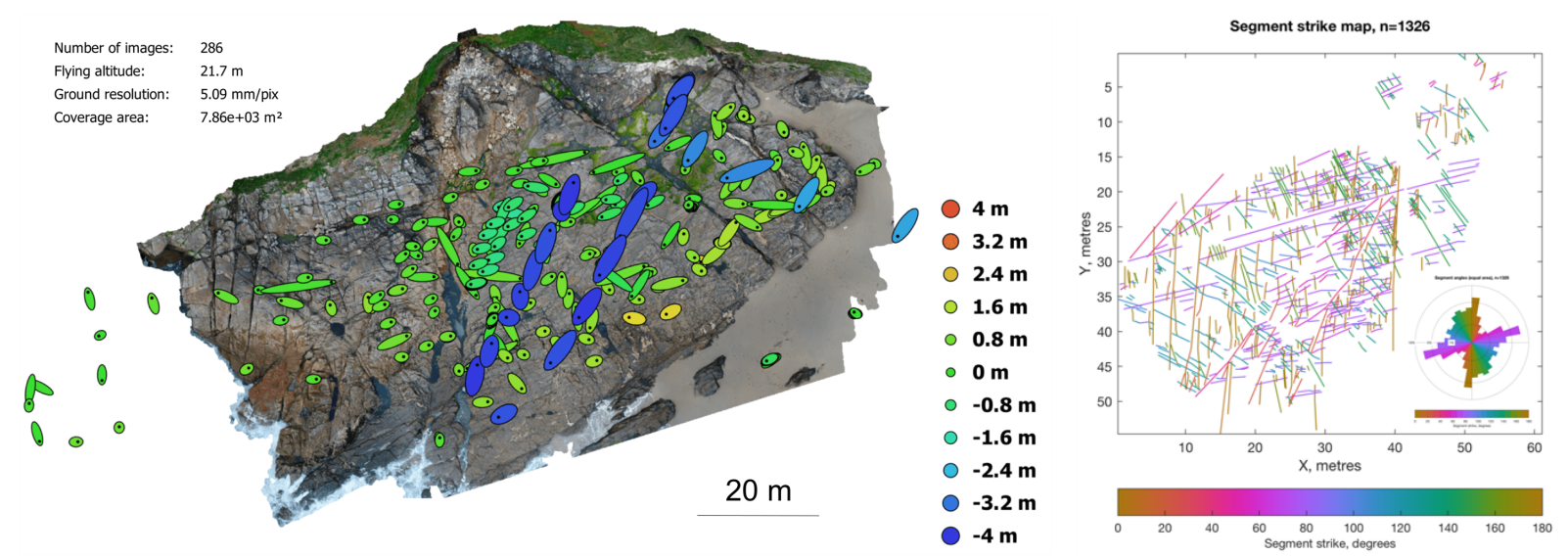

Fig. 1. a. Orthomosaic of Rinsey Cove outcrop in south Cornwall mapped using UAV-acquired aerial photography. Camera locations and error estimates. Estimated camera locations are marked with a black dot. $Z$ error is represented by ellipse colour. X,Y errors are represented by ellipse shape. $b$. Fracture map of granite outcrop showing fracture orientations. Inset: rose diagram of traced fractures.

\section{Conclusions}

The contrasting geological conditions between our two case studies help outline different risks present in underground operations with diverse geological settings. In this case, different lithology, tectonic setting and fracture-dominated versus fracture- and matrix-dominated permeability. Induced seismicity risk and productivity decay are the main concerns of the Husmuli field, primarily driven by the activity of the South Iceland Seismic Zone and the continuous divergence of tectonic plates in the area. In contrast, the Cornish field presents big unknowns, including permeability values of the reservoir and their evolution in time, the long-term effect of fluid rock interaction along the fault zone, and the potential of the structure for induced seismicity. Identifying and actively tackling the risks of these fields is the principal concern of the S4CE project, making these two examples optimal to apply new technologies with the potential to provide fantastic learning opportunities for a sustainable future.

Iceland's development of geothermal energy has put it at the head of the pack in terms of technological advancements and building an environmentally sustainable community. Over half of the nation's electricity is produced from geothermal sources and the waste products are used to heat homes, roads and major infrastructure. The country is investigating export potential and is actively leveraging its access to clean energy in order to promote a fairer society through gender equality. Although Cornwall's geothermal potential is lower, United Downs is best positioned in the UK to exploit the country's deep geothermal resources. Few countries around the world can rival Iceland for its geological power, but if progress can be made at UDDGP then the knowledge gained through this project could be used to develop more challenging geothermal reservoirs elsewhere in the world.

\section{Acknowledgements}

The authors would like to thank all partners in the S4CE project, especially the collaboration with and access to data from Reykjavik Energy and the United Downs Geothermal Project.

\section{References}

Einarsson, P. [2008] Plate Boundaries, Rifts and Transforms in Iceland. Jokull, 58, 35-58.

Gunnarson, G. and Mortensen, A. [2016] Dealing with intense production density: Challenges in understanding and operating the Hellisheiði Geothermal Field, SW-Iceland. Proceedings, $41^{\text {st }}$ Workshop on Geothermal Reservoir Engineering Stanford University, Stanford, California, February 22-24, 2016.

Hardarson B.S., Einarsson, G.M., Franzson, H. and Gunnlaugsson, E. [2009] Volcano-tectonic-geothermal interaction at the Hengill triple junction, SW Iceland. GRC Transacions, 33, p. 49-55. 
Healy, D., Rizzo, R., Cornwell, D., Farrell, N., Watkins, H., Timms, N., Gomez-Rivas, E. and Smith, M. [2016] FracPaQ: A MATLAB ${ }^{\mathrm{TM}}$ toolbox for the quantification of fracture patterns. Journal of Structural Geology. 95. 10.1016/j.jsg.2016.12.003.

Leveridge, B.E., Holder, M.T. and Day, G.A. [1984] Thrust nappe tectonics in the Devonian of south Cornwall and the western English Channel. In: Hutton, D.H.W. and Sanderson, D.J. (Eds), Variscan tectonics of the North Atlantic region. Special Publication of the Geological Society, London, 14, 103-112.

Leveridge, B.E., Holder, M.T. and Goode, A.J.J. [1990] Geology of the country around Falmouth. Memoir of the British Geological Survey, 352 (England and Wales).

Oelkers, E.H., Gislason, S. R., Matter, J. [2008] Mineral Carbonation of CO2. Elements; 4 (5): $333-337$.

Pine, R. J. and Ledingham P. [1983] In situ hydraulic parameters for the Carnmenellis granite hot dry rock geothermal energy research reservoir. SPE 12020. In SPE 58th Arm. Tech. Conf. and Exhibition, San Francisco (October).

Rattey, P.R. and Sanderson, D.J. [1984] The structure of SW Cornwall and its bearing on the emplacement of the Lizard Complex. Journal of the Geological Society, London, 141, 87-95.

Richards, H.G., Savage, D. and Andrews, J.N. [1992] Granite-water reactions in an experimental hot dry rock geothermal reservoir, Rosemanowes test site, Cornwall, U.K. Applied Geochemistry, 7 (3), 193-222.

Shail, R.K. and Wilkinson, J.J. [1994] Late to post-Variscan extensional tectonics in south Cornwall. Proceedings of the Ussher Society, 8, 262-270. 